\title{
A Case Report of Prostatic and Peritoneal Hemangioendothelioma
}

\section{Prostatik ve Peritoneal Hemanjiyoendoteliyoma: Bir Olgu Sunumu}

\author{
(1) Michael Lao', (1) Boulos Beshai ${ }^{2}$, (1) Andrew Ricci ${ }^{2}$, (1) Joseph Wagner ${ }^{1}$ \\ ${ }^{1}$ Hartford Hospital, Clinic of Urology, Hartford, Connecticut, USA \\ ${ }^{2}$ Hartford Hospital, Clinic of Pathology, Hartford, Connecticut, USA
}

\begin{abstract}
Epithelioid hemangioendothelioma is a rare endothelial neoplasm that is uncommonly described in the urinary system. To date, only one case has been described as originating from the prostate. We report a second case of prostatic epithelioid hemangioendothelioma, this one in a 71-year-old man. Epithelioid hemangioendothelioma was found on transurethral resection of the prostate with discovery of extensive peritoneal dissemination. Keywords: Hemangioendothelioma, Vascular neoplasms, Prostatic neoplasms
\end{abstract}

\section{Öz}

Epiteloid hemanjiyoendoteliyoma; ürolojik sistemde olağandışı olarak tanımlanan nadir bir endotelyal neoplazmdır. Bugüne kadar, prostattan kaynaklanan tek bir olgu tarif edilmiştir. Bu yazıda; 71 yaşındaki bir erkek hastada, literatürde ikinci olarak görülen bir prostatik epiteloid hemanjiyoendoteliyoma olgusu sunulmuştur. Epiteloid hemanjiyoendoteliyoma, prostatın transüretral rezeksiyonu sırasında geniş peritoneal yayılımın görülmesi ile saptanmıştır.

Anahtar Kelimeler: Hemanjiyoendoteliyoma, Vasküler neoplazmlar, Prostatik neoplazmlar

\section{Introduction}

Epithelioid hemangioendothelioma (EHE) is a rare endothelial neoplasm first described by Weiss and Enzinger (1) in 1982. EHE is part of a family of hemangioendotheliomas and is characterized by proliferation of epithelioid endothelial cells. It is thought to have biologic behavior intermediate between that of hemangiomas and angiosarcomas (2). Initially believed to be characterized by low malignant potential, however, it is now documented to have high local recurrence potential, and even metastatic risk in nearly one-third of cases (3).

EHE occurs at a spectrum of ages most commonly involving the soft tissues, lungs, liver, and bones. Rarely is it found in the urinary system (4) and to date only one case has been described as originating from the prostate (3). Here, we present a case of EHE initially found on transurethral resection of the prostate (TURP) with subsequent discovery of extensive peritoneal involvement.

\section{Case Presentation}

A 71-year-old man with a significant cardiovascular medical history as well as benign prostatic hyperplasia (BPH) and renal cell carcinoma presented with 1 week of painless gross hematuria and lightheadedness. One month previously, he had open infra-renal aortic aneurysm repair and removal of infected stent graft with subsequent aortobifemoral bypass. Computed tomography (CT) scan of the abdomen and pelvis showed a possible endovascular leak and what was thought to be a $3.0 \times 3.0 \mathrm{~cm}$ prostatic abscess in the right lobe of the prostate.

Due to the signs of sepsis and his recent history of aneurysm repair and grafting, the patient was placed on broad spectrum antibiotics and taken urgently to the operating room for drainage of the prostatic abscess via TURP. The left lobe of the prostate had the typical appearance of BPH. The tissue in the right lobe was clearly abnormal; a thick white material was encountered, but no frank abscess was identified.

Correspondence: Joseph Wagner MD, Hartford Hospital, Clinic of Urology, Hartford, Connecticut, USA

E-mail: joseph.wagner@hhchealth.org ORCID-ID: orcid.org/0000-0002-9172-9897

Received: 09.05.2017 Accepted: 17.07.2017

Cite this article as: Lao M, Beshai B, Ricci A, Wagner J. A Case Report of Prostatic and Peritoneal Hemangioendothelioma. J Urol Surg 2018;5(3):188-190.

๑Copyright 2018 by the Association of Urological Surgery / Journal of Urological Surgery published by Galenos Publishing House. 
Histologic analysis revealed adenomatous and fibromuscular stromal hyperplasia with chronic active inflammatory changes, squamous metaplasia of prostatic ducts, bland infarction and reactive glandular and stromal atypia. Dissecting in-between benign prostatic ducts and acini were solid clusters of atypical epithelioid cells with ample eosinophilic cytoplasm and limited lumen formation. Occasional characteristic "blister cells" were noted. Mitoses were rare. No overt malignant cytologic features were seen with no evidence of hemorrhagic necrosis. Immunohistochemical assays from cluster of differentiation 31 , cluster of differentiation 34, factor 13a, friend leukemia integration-1 transcription factor and erythroblast transformation-specific-related gene were positive consistent with vascular phenotype and denying prostatic carcinoma. Histology was interpreted as vascular tumor of intermediate malignant potential (i.e. EHE, Figure 1).

After TURP, the patient had an unstable clinical course and continued to deteriorate. CT angiogram showed large fluid collections measuring $8.6 \mathrm{~cm}$ and $5.7 \mathrm{~cm}$. Given the patient's clinical course, he was brought to surgery where exploratory laparotomy revealed 5 liters of blood clot and peritoneal cancerous dissemination involving the small bowel, peritoneal walls, and omentum. It was unclear whether the fluid collections were iatrogenic seromas or malignant ascites. Initial frozen section indicated malignancy and final pathology revealed

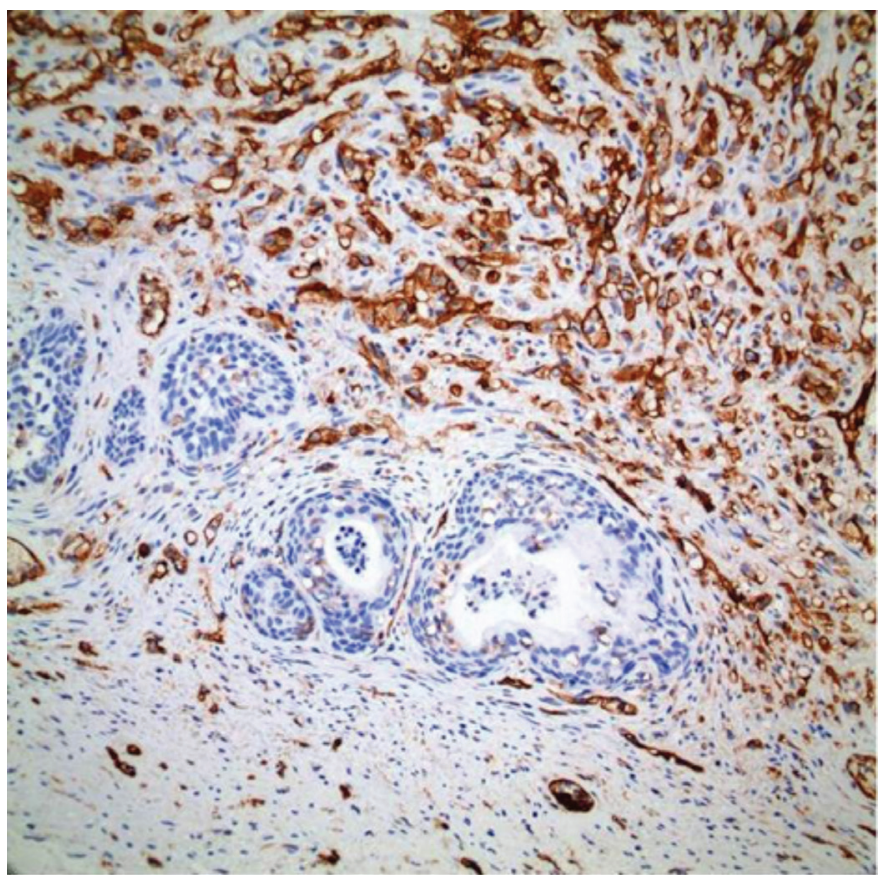

Figure 1. Prostate (transurethral resection of the prostate), cluster of differentiation 31, original magnification, 200x: cluster of differentiation 31 highlights the cytoplasm and membranes of infiltrative tumor cells, sparing normal prostatic glands and stroma, with a strong internal control expression in normal blood vessels. Such strong cluster of differentiation 31 positivity confirms the neoplasm's vascular origin malignant EHE. Peritoneal histology was of higher grade than the prostate tumor, resembling epithelioid angiosarcoma (Figure 2). The patient expired shortly thereafter.

All of the procedures described in this report were standard of care. The patient provided informed consent for the standard of care procedures described per hospital requirements, however no informed consent for research was needed as this was not a research study.

\section{Discussion}

EHE is a rare endothelial vascular neoplasm. The incidence is less than 0.1 per 100.000 people, and the mean age at diagnosis is 42 years with a slight female prevalence (5). EHE usually originates in soft tissues, liver, lungs, or bone; rarely has it been reported to originate in the urinary system. When discovered in the bladder, the common presenting complaint is hematuria (4). When involving the kidney, it can be discovered on imaging as a heterogeneous mass (6). In our patient, imaging suggested the possibility of a prostatic abscess. EHE typically has a better prognosis than classic angiosarcoma, but with higher potential for metastatic disease than other hemangioendotheliomas (2).

The diagnosis of EHE cannot be made on imaging studies but rather requires a biopsy for histologic and immunohistochemical examination. The differential diagnosis should always include primary or metastatic epithelioid angiosarcoma, and even poorly

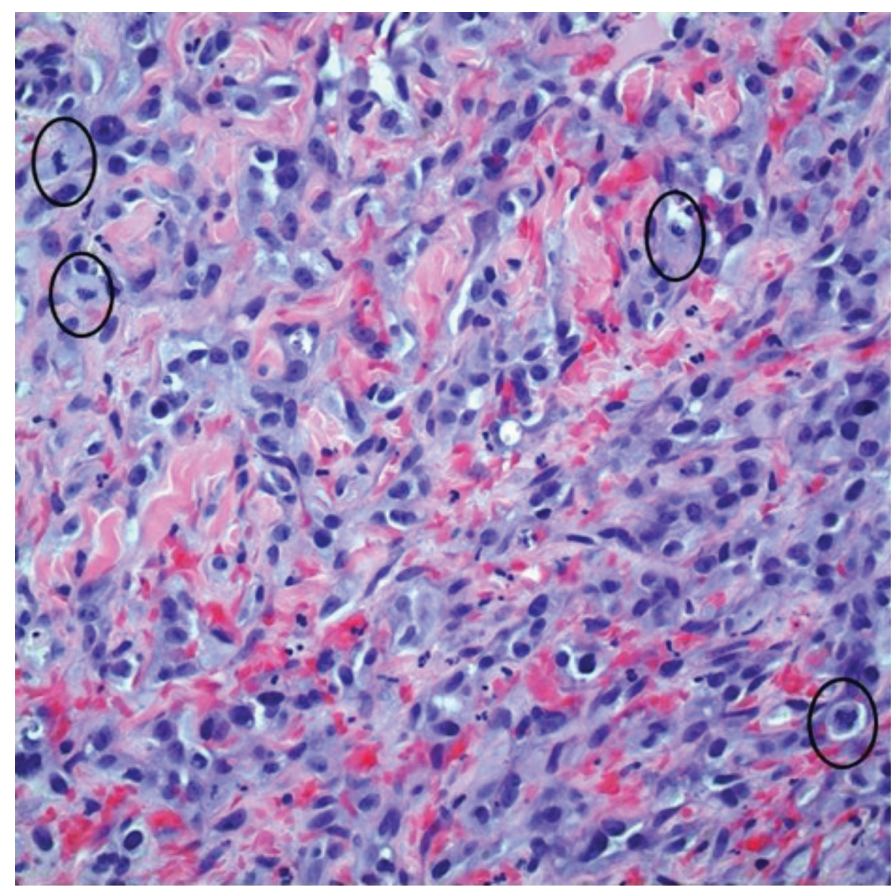

Figure 2. Peritoneal nodule, hematoxylin and eosin, original magnification, 400x: in contrast to tumor cells seen in prostatic primary, the epithelioid cells here show higher grade of atypia, pleomorphism, and hyperchromasia. In addition, increased mitotic activity is present (circles) 
differentiated prostatic carcinoma (3). In the case presented here, the differential diagnosis also included prostate abscess, prostate adenocarcinoma, and a non-adenocarcinomatous cancer of the prostate. In contrast to EHE, angiosarcoma shows a greater degree of cellular pleomorphism, nuclear hyperchromatism, necrosis, and higher mitotic rate. There are no clear cut radiographic features to strongly suggest EHE, but there are some features that might be commonly seen. Imaging might reveal evidence of a mass that is often solid in appearance. Contrast-enhanced CT might reveal heterogeneous hypodense nodules with a ring-like low density border and a lower density center. Magnetic resonance imaging might show heterogeneous hypointense lesions on T1-weighted images and hypertense lesions on T2-weighted images (7).

Due to its rarity, no consensus exists on the management of urologic EHE. Clinical behavior can vary depending on the site of the disease. Surgical resection with clear margins should be performed if possible. In those with inoperable disease, a period of observation to assess tumor behavior is reasonable. Durable spontaneous regression has been reported (8). The role of medical therapy remains unclear. It is uncertain if pharmacological options have any real efficacy given the variable natural history of urologic EHE. Management has included chemotherapy and drugs that exploit angiogenic pathways and receptors for vascular endothelial growth factor. Studies have also reported using paclitaxel, bevacizumab, sunitinib, interferon-alpha, doxorubicin, 5-fluorouracil, cyclophosphamide, vinblastine, carboplatin, thalidomide, and etoposide (9). A novel gene fusion product, WWTR1-CAMTA-1 may inform future therapies (10). Radiotherapy has no place in the management of these tumors. The current report illustrates the differential diagnosis and management of this rare condition in a case that is particularly unique as it originated in the prostate. To our knowledge, ours' is only the second such case to be presented in the literature.

\section{Acknowledgements}

We thank Tara McLaughlin, PhD for her administrative and editorial assistance in revising and preparing this manuscript for publication.

\section{Ethics}

Informed Consent: All of the procedures described here were standard of care. The patient provided informed consent for the standard of care procedures described, however no informed consent for research was needed as this was not a research study.

Peer-review: Externally and internally peer-reviewed.

\section{Authorship Contributions}

Surgical and Medical Practices: J.W., M.L., B.B., Concept: J.W., M.L., B.B., A.R., Design: J.W., M.L., B.B., A.R., Data Collection or Processing: J.W., M.L., B.B., A.R., Analysis or Interpretation: J.W., M.L., B.B., A.R., Literature Search: M.L., B.B., Writing: J.W., M.L., B.B., A.R.

Conflict of Interest: No conflict of interest was declared by the authors.

Financial Disclosure: The authors declared that this study received no financial support

\section{References}

1. Weiss SW, Enzinger FM. Epithelioid hemangioendothelioma: a vascular tumor often mistaken for a carcinoma. Cancer 1982;50:970-981.

2. Requena L, Kutzner H. Hemangioendothelioma. Semin Diagn Pathol 2013;30:29-44.

3. Iyer A, Thompson L, Cooper K. Epithelioid haemangioendothelioma, mimicking prostatic adenocarcinoma. Histopathology 2012;60:522-524.

4. Liu B, Zhang C, Zhang O, Liu G, Ma Z, Qi J, Xin Q, Wen L. Primary epithelioid hemangioendothelioma of the bladder: Case report and review of the literature. Urol Int 2015;94:240-243.

5. Mehrabi $A$, Kashfi $A$, Fonouni $H$, Schemmer $P$, Schmied BM, Hallscheidt $P$, Schirmacher $P$, Weitz J, Friess $H$, Buchler MW, Schmidt J. Primary malignant hepatic epithelioid hemangioendothelioma: a comprehensive review of the literature with emphasis on the surgical therapy. Cancer 2006;107:2108-2121.

6. Xiao $Y$, Wang $C$, Song $Y$, Wang $C$, Wang $X$, Zhang $X, X u$ A. Primary epithelioid hemangioendothelioma of the kidney: The first case report in a child and literature review. Urology 2013;82:925-927.

7. Lin J, Ji Y. CT and MRI diagnosis of hepatic epithelioid hemangioendothelioma. Hepatobiliary Pancreat Dis Int 2010;9:154-158.

8. Kitaichi $M$, Nagai $S$, Nishimura $K_{1}$ Itoh $H$, Asamoto $H$, Izumi T, Dail DH. Pulmonary epithelioid haemangioendothelioma in 21 patients, including three with partial spontaneous regression. Eur Respir J 1998;12:89-96.

9. Yousaf N, Maruzzo M, Judson I, Al-Muderis O, Fisher C, Benson C. Systemic treatment options for epithelioid haemangioendothelioma: the Royal Marsden Hospital experience. Anticancer Res 2015;35:473-480.

10. Errani C, Zhang L, Sung YS, Hajdu M, Singer S, Maki RG, Healey JH, Antonescu CR. A novel WWTR1-CAMTA1 gene fusion is a consistent abnormality in epithelioid hemangioendothelioma of different anatomic sites. Genes Chromosomes Cancer 2011;50:644-653. 